\title{
Self-directed learning readiness mahasiswa di masa pandemi Covid-19
}

\author{
Yudha Nata Saputra
}

Sekolah Tinggi Teologi Cipanas, Jawa Barat yudhanata99@gmail.com

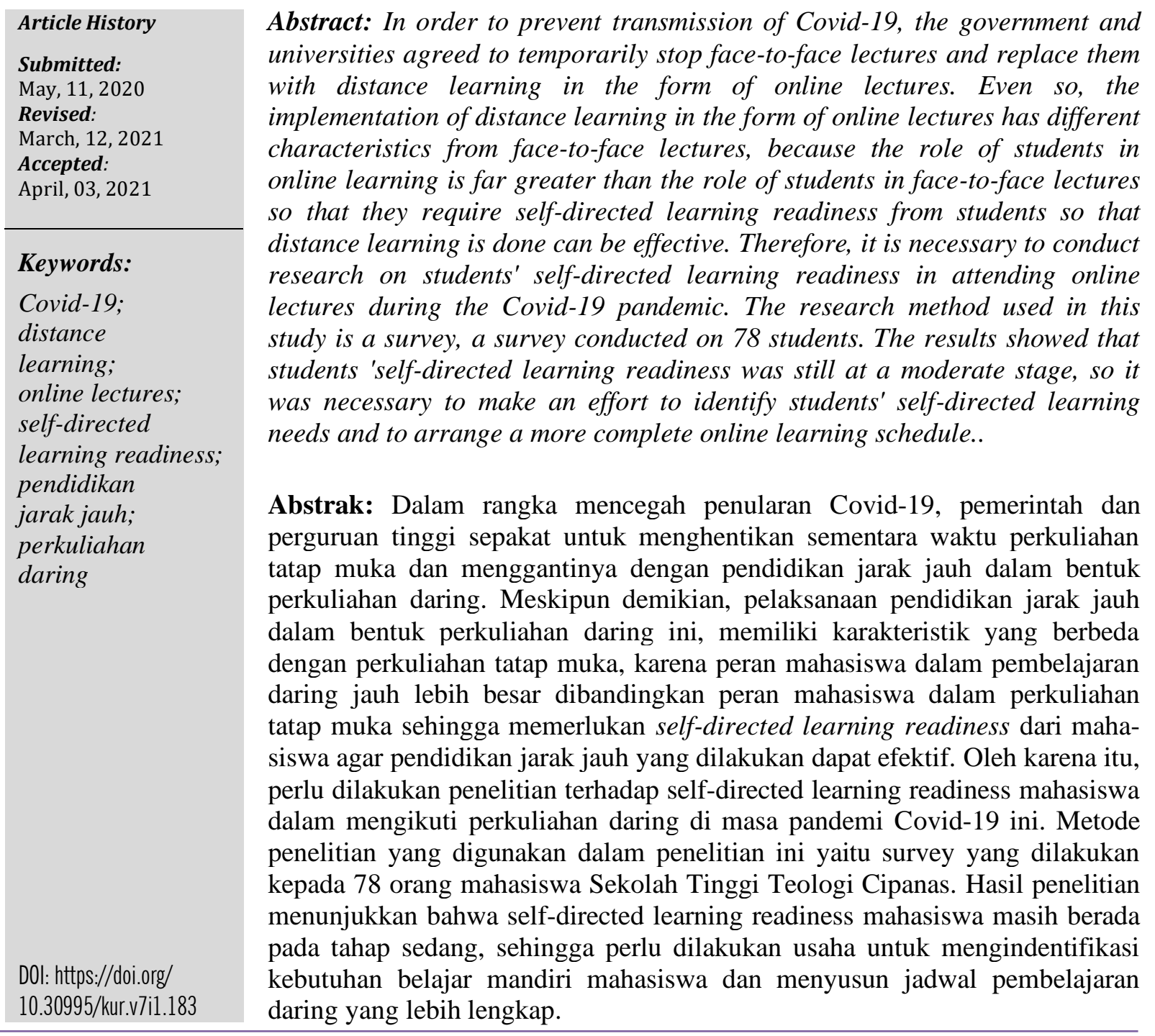

\section{Pendahuluan}

Pandemi Corona Virus Disease (Covid-19) yang melanda dunia, tidak terkecuali Indonesia membuat Presiden Jokowi mengajak masyarakat agar melaksanakan kegiatan bekerja, belajar dan beribadah di rumah demi mencegah penyebaran Covid-19 di Indonesia. Sejalan dengan himbauan pemerintah ini, maka Kemendikbud mengeluarkan Surat Edaran Nomor 36962/MPK.A/HK/2020 tentang Pembelajaran secara Daring dan Bekerja dari Rumah dalam Rangka Pencegahan Penyebaran Covid-19, salah satunya ditujukan kepada seluruh Pimpinan 
Perguruan Tinggi Negeri/Swasta. Salah satu poin penting dari surat edaran ini, yaitu memberlakukan pembelajaran dari rumah bagi siswa dan mahasiswa. ${ }^{1}$ Demikian pula Menteri Agama, Fachrul Razi meminta agar Perguruan Tinggi Keagamaan (PTK) mengambil kebijakan yang tegas untuk mencegah penyebaran virus Corona dengan memberlakukan kegiatan belajar mengajar jarak jauh, termasuk agar pengelola perguruan tinggi agama dan keagamaan bersinergi dan menyesuaikan dengan kebijakan Kemendibud dan Pemerintah Daerah. ${ }^{2}$ Sejalan dengan hal itu, maka untuk menyikapi penyebaran Covid-19 yang semakin hari semakin meningkat, maka Pimpinan STT Cipanas mengeluarkan Surat Edaran Nomor 014/STTC/KIII/2020, di mana salah satu poinnya yaitu meniadakan perkuliahan di kampus (tatap muka) dan menggantinya dengan perkuliahan on line dari tanggal 19 Maret 2020 sampai dengan 19 April 2020. ${ }^{3}$ Selanjutnya melalui Surat Edaran Nomor 017/STTC/K/IV/2020 perihal Perpanjangan aktivitas perkuliahan online, STT Cipanas memperpanjang perkuliahan online sampai dengan tanggal 1 Juni $2020{ }^{4}$

Melihat kondisi penyebaran Covid-19 yang semakin hari semakin meningkat, mau tidak mau masyarakat sebisa mungkin harus menghindari aktivitas bertemu banyak orang, di mana salah satunya kegiatan pembelajaran juga harus dilakukan tanpa tatap muka yang selama ini dikenal dengan Pendidikan Jarak Jauh (PJJ), pembelajaran daring merupakan salah satu modus PJJ. Salah satu karakteristik yang membedakan PJJ dengan kuliah tatap muka, yaitu antara dosen dan mahasiswa tidak saling bertatap muka di dalam kelas seperti kuliah pada umumnya tapi interaksi pembelajaran digantikan melalui bantuan media yang mendukung PJJ, dari mulai yang sederhana seperti melalui modul perkuliahan sampai kepada yang canggih dengan menggunakan internet. Kegiatan PJJ, sebenarnya bukanlah sesuatu yang asing sama sekali untuk dunia pendidikan tinggi di Indonesia, jauh sebelum pandemi Covid19 muncul, Universitas Terbuka (UT) sudah melaksanakan PJJ yang ditujukan kepada caloncalon mahasiswa yang karena situasinya tidak memungkinkan untuk mengikuti perkuliahan tatap muka biasa, bisa mengikuti perkuliahan di UT. Bahkan sebelum berkembangnya pemanfaatan teknologi informasi dalam PJJ, pelaksanaan perkuliahan menggunakan sistem modul, di mana mahasiswa mempelajari modul-modul perkuliahan secara mandiri, kemudian diadakan tutorial setiap semesternya. Seiring dengan perkembangan teknologi informasi dan pemanfatannya dalam dunia pendidikan maka model perkuliahan di UT tidak hanya mengandalkan modul saja tapi juga menggunakan media internet melalui aktivitas tutorial secara online yang dilakukan oleh tuton dan mahasiswa.

Dahulu, aktivitas PJJ bisa dikatakan menjadi "monopoli" UT, pemerintah tidak mengijinkan untuk perguruan tinggi mengadakan aktivitas pendidikan jarak jauh karena alasan sulitnya memantau mutu pendidikan yang diselenggarakan. Seiring dengan waktu, saat

\footnotetext{
${ }^{1}$ Mendikbud, 'Surat Edaran Mendikbud No. 35952/MPK.A/HK/2020 Tentang Pembelajaran Secara Daring Dan Bekerja Dari Rumah Dalam Rangka Pencegahan Penyebaran Corona Virus Disease (Covid-19)', Produk Hukum, 2020, pp. 1-2 <https://www.kemdikbud.go.id/main/blog/2020/03/se-mendikbud-pembelajaransecara-daring-dan-bekerja-dari-rumah-untuk-mencegah-penyebaran-covid19>.

${ }^{2}$ Kontri, 'Menag Minta Pimpinan PTK Ambil Langkah Tegas Cegah Corona', Kementerian Agama, 2020 <https://kemenag.go.id/berita/read/513018/menag-minta-pimpinan-ptk-ambil-langkah-tegas-cegahcorona $>$ [accessed 10 May 2020].

${ }^{3}$ Martin Elvis, 'Surat Edaran Terkait Sikap STT Cipanas Terhadap Covid-19', 2020, pp. 1-2.

${ }^{4}$ Martin Elvis, 'Perpanjangan Aktivitas Perkuliahan Online', 2020, pp. 1-2.
} 
ini pemerintah telah mengijinkan pendidikan jarak jauh dengan sejumlah persyaratan termasuk instrumen akreditasi untuk pendidikan jarak jauh pun sudah disediakan oleh BANPT (Badan Akreditasi Nasional Perguruan Tinggi). PJJ, memang memiliki karakteristik yang unik jika dibandingkan dengan pendidikan tatap muka konvensional, karena interaksi antara mahasiswa dan dosen dijembatani melalui perantaraan media, tidak langsung bertatap muka. Akibatnya faktor keberhasilan dalam aktivitas PJJ selain ditentukan oleh media yang digunakan juga akan sangat ditentukan juga oleh kesiapan mahasiswa dalam belajar mandiri "Self-Directed Readiness Learning".

Tentu dalam situasi saat ini, mengharapkan keberhasilan pendidikan jarak jauh kepada media yang digunakan bisa dikatakan sesuatu yang sifatnya mustahil, karena pendidikan jarak jauh yang dilaksanakan saat ini dilaksanakan dalam situasi darurat. Di mana sifatnya mendadak dalam rangka menghadapi situasi pandemi Covid-19, sehingga mengharapkan hasil yang optimal dari pelaksanaan PJJ juga sulit. Meskipun demikian, melalui pemanfaatan media sosial, email, dan sejumlah platform media pembelajaran online yang tersedia maka pelaksanaan PJJ dalam situasi darurat ini, dapat mengatasi persoalan jarak dan waktu sehingga kegiatan pembelajaran di perguruan tinggi masih tetap dapat berjalan. Dalam siarannya, Plt. Direktur Jenderal Pendidikan Tinggi, Nizam mengatakan bahwa dalam satu bulan, 94.73\% mahasiswa sudah melakukan pembelajaran secara daring, meskipun masih banyak kendala yang ditemui mulai dari koneksi internet, aplikasi yang digunakan, kualitas penyajian dan fasilitas. ${ }^{5}$ Hal ini menunjukkan bahwa dalam berbagai keterbatasannya PJJ sangat mungkin dilaksanakan dalam situasi sekarang.

Meskipun karakteristik PJJ sangat bergantung kepada keberadaan teknologi dalam pelaksanaannya tapi satu hal yang paling penting adalah kepada persoalan self-directed learning readiness mahasiswanya. Beberapa penelitian terkait self-directed learning readiness mahasiswa sudah banyak dilakukan di Universitas Terbuka sebagai pelopor PJJ di Indonesia, Kusmawan melakukan penelitian terhadap Self-directed learning readiness Guru Sekolah Dasar yang menjadi mahasiswa pada Program Studi PGSD FKIP Universitas Terbuka. ${ }^{6}$ Puspitasari dan Islam melakukan penelitian Self-directed learning readiness Mahasiswa dan Calon Mahasiswa pada Pendidikan Jarak Jauh di Indonesia. ${ }^{7}$ Darmayanti meneliti tentang efektivitas intervensi keterampilan self-regulated learning dan keteladanan dalam meningkatkan kemampuan belajar mandiri dan prestasi belajar mahasiswa pendidikan

${ }^{5}$ Humas Ditjen Dikti, 'Kebijakan Dan Penelitian Perguruan Tinggi Untuk Hadapi Pandemi Covid-19 Dikti Official Site', Kementerian Pendidikan Dan Kebudayaan, 2020 <http://www.dikti.go.id/kabar/ditjen-diktiberupaya-mendorong-dan-berfokus-pada-kebijakan-progam-menghadapi-pandemi-covid-19/> [accessed 10 May 2020].

${ }^{6}$ Udan Kusmawan, 'Kesiapan Belajar Mandiri Guru Sekolah Dasar Sebagai Mahasiswa Pada Program Studi Pgsd Fkip Universitas Terbuka Self-Directed Learning Readiness of Elementary School Teacher As Student of Open University', Jurnal Pendidikan Dan Kebudayaan, 1 (2016), 279-93 $<$ http://jurnaldikbud.kemdikbud.go.id>.

${ }^{7}$ Kristanti Ambar Puspitasari and Samsul Islam, 'Kesiapan Belajar Mandiri Mahasiswa Dan Calon Potensial Mahasiswa Pada Pendidikan Jarak Jauh Di Indonesia', Jurnal Pendidikan Terbuka Dan Jarak Jauh, 4.1 (2003), 1-13 <http://simpen.lppm.ut.ac.id/ptjj/PTJJ Vol 4.1 maret 2003/41kristanti.htm>. 
jarak jauh. ${ }^{8}$ Sebelum itu Darmayanti juga meneliti tentang Hubungan Self-directed learning readiness dengan Prestasi Belajar Mahasiswa Universitas Terbuka. ${ }^{9}$ Beberapa penelitian berkenaan dengan Self-directed learning readiness pada PJJ yang dilaksanakan Universitas Terbuka menunjukkan bahwa self-directed learning readiness sangat penting dalam menunjang keberhasilan mahasiswa dalam mengikuti PJJ. Mahasiswa yang tidak memiliki self-directed learning readiness akan terhambat dalam mengikuti PJJ yang saat ini dilaksanakan oleh mayoritas lembaga pendidikan di Indonesia dari mulai pendidikan dasar, menengah sampai tinggi tidak terkecuali perguruan tinggi keagamaan seperti Sekolah Tinggi Teologi (STT).
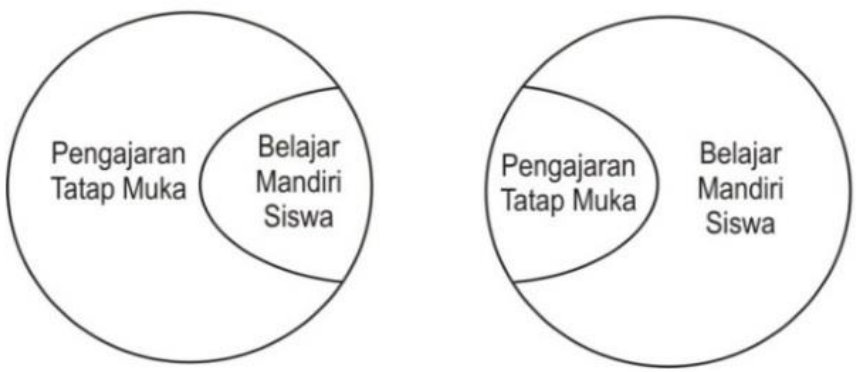

Gambar 1: Perbedaan Pendidikan Tatap Muka dan Pendidikan Jarak Jauh (Suparman dan Zuhairi 2004) $^{10}$

Gambar di atas, menunjukkan bahwa aspek self-directed learning readiness mahasiswa merupakan sesuatu yang penting sebagai kunci keberhasilan dalam PJJ. Self-directed learning readiness mahasiswa dalam mengikuti PJJ menjadi penting, karena dalam model pendidikan jarak jauh, mahasiswa yang lebih banyak menentukan aktivitas pembelajaran dengan intervensi lingkungan fisik dan sosial yang rendah. Dalam pembelajaran tatap muka, kehadiran mahasiswa di dalam kelas dikontrol dengan ketat oleh dosen, demikian pula keaktifan mahasiswa akan dapat dilihat secara langsung oleh dosen bahkan teman-temannya. Tapi tidak demikian dalam modus PJJ, intervensi lingkungan fisik dan sosial tidak sebesar dalam pembelajaran tatap muka, mahasiswa yang tidak memiliki self-directed learning readiness, akan dengan mudah menghindari aktivitas pembelajaran yang dilakukan, cukup dengan mematikan media yang digunakan dalam pembelajaran dengan berbagai alasannya. Demikian juga intervensi yang diperoleh dari teman-teman sekelas tidak sekuat dalam modus pembelajaran tatap muka, dalam pembelajaran tatap muka, mahasiswa akan banyak berinteraksi dengan teman-teman di kelas, sehingga tugas-tugas, ujian, ketidakhadiran akan lebih banyak terkontrol. Hal demikian akan berbeda dengan modus PJJ, di mana interaksi sosial dilakukan melalui perantaraan media, sehingga disinilah peranan self-directed learning

${ }^{8}$ Tri Darmayanti, 'Efektivitas Intervensi Keterampilan Self-Regulated Learning Dan Keteladanan Dalam Meningkatkan Kemampuan Belajar Mandiri Dan Prestasi Belajar Mahasiswa Pendidikan Jarak Jauh’ (Universitas Indonesia, 2005).

${ }^{9}$ Tri Darmayanti, 'Readiness for Self Directed Learning and Achievement of the Student of Universitas Terbuka (The Indonesian Open Learning University)’ (University of Victoria, 1993).

${ }^{10}$ Kusmawan. 
readiness mahasiswa menjadi sangat penting, karena akan menjadi kunci keberhasilan pelaksanaan PJJ dalam situasi saat ini.

Karakteristik pendidikan jarak jauh, memang akan memperbesar peran mahasiswa dalam belajar sebaliknya mengurangi peran dosen dan sebaliknya akan memperbesar peran media, sehingga dalam situasi saat ini, maka pengukuran terhadap self-directed learning readiness mahasiswa akan jauh lebih penting daripada mengukur aspek kompetensi dosen maupun kesiapan media pembelajaran mengingat situasi yang dihadapi adalah situasi darurat. STT sebagai salah satu bentuk pendidikan tinggi keagamaan, yang juga merupakan salah satu lembaga pendidikan yang terdampak dari pandemi Covid-19 ini, sehingga aktivitas pembelajaran tatap muka pun terpaksa digantikan melalui modus pendidikan jarak jauh. Artinya, situasi yang sama dihadapi bukan saja oleh perguruan tinggi umum tapi juga perguruan tinggi keagamaan, seperti STT. Mengingat, aspek keberhasilan pendidikan jarak jauh saat ini lebih banyak ditentukan oleh faktor mahasiswa yang juga sudah ditunjukkan oleh beberapa hasil penelitian sebelumnya, maka perlu untuk melihat profil self-directed learning readiness mahasiswa teologi dalam melaksanakan PJJ di masa pandemi Covid-19 ini. Dengan demikian maka rumusan masalah dalam penelitian ini, "Bagaimana Self-directed learning readiness Mahasiswa Teologi dalam Melaksanakan PJJ di masa Pandemi Covid-19?." Adapun yang menjadi tujuan penelitian ini, yaitu untuk menganalisa self-directed learning readiness mahasiswa teologi dalam melaksanakan PJJ di masa Pandemi Covid-19. Melalui analisa terhadap self-directed learning readiness mahasiswa teologi dalam melaksanakan PJJ di masa pandemi Covid-19 ini, maka akan dapat diambil kebijakan untuk meningkatkan efektivitas modus PJJ yang sedang dilaksanakan.

\section{Metode Penelitian}

Penelitian ini merupakan penelitian survey yang dilakukan kepada mahasiswa Program Studi Sarjana Teologi STT Cipanas, Jawa Barat. Tujuannya untuk menganalisa self-directed learning readiness mahasiswa teologi dalam melaksanakan PJJ di masa pandemi Covid-19. Kasunic (2005) menjelaskan bahwa penelitian survey adalah penelitian yang mengumpulkan informasi dari sejumlah kecil sampel untuk ditarik generalisasi ${ }^{11}$. Dalam rangka mendapatkan data yang dibutuhkan, maka variabel self-directed learning readiness mahasiswa dalam penelitian ini perlu dioperasionalisasikan ke dalam indikator-indikator yang dapat diukur sehingga menggambarkan jenis data dan informasi yang diperlukan. Berdasarkan jenis data dan informasi tersebut maka dilakukan analisa secara statistik untuk bisa menjawab masalah yang telah di rumuskan dalam penelitian ini. Merujuk kepada pendapat Candy $(1991)^{12}$ terdapat empat dimensi belajar mandiri, yaitu otonomi diri atau personal autonomy, pengelolaan diri atau self-management, kebutuhan belajar yang mandiri atau the independent

${ }^{11}$ Yulianasyah, Meningkatkan Response Rate Pada Penelitian Survey Suatu Studi Literature (Jakarta: SMART, 2016).

${ }^{12}$ Philip C Candy, Self-Direction for Lifelong Learning , A Comprehensive to Theory and Practice (San Fransisco: Jossey-Bass Inc, 1991). 
pursuit of learning, dan kontrol pembelajar terhadap pembelajaran atau learner-control of instruction. ${ }^{13}$

Tabel 1. Operasionalisasi Variabel

\begin{tabular}{|c|c|c|}
\hline Variabel & Dimensi & Indikator \\
\hline \multirow{4}{*}{$\begin{array}{l}\text { Self-directed } \\
\text { learning } \\
\text { readiness } \\
\text { Mahasiswa }\end{array}$} & Otonomi Diri & $\begin{array}{l}\text { - Memiliki tujuan hidup } \\
\text { - } \text { Bebas menentukan pilihan } \\
\text { - Mampu menggunakan } \\
\text { kemampuan diri untuk refleksi } \\
\text { - Mang rasional } \\
\text { - Mempunyai kemauan yang kuat } \\
\text { - } \text { Disiplin diri } \\
\text { - Melihat dirinya sebagai orang } \\
\text { yang mandiri }\end{array}$ \\
\hline & Pengelolaan Diri & $\begin{array}{ll}\text { - } & \text { Kemauan untuk mengelola diri } \\
\text { - } & \text { Kemampuan untuk mengelola diri }\end{array}$ \\
\hline & Kebutuhan Belajar Mandiri & $\begin{array}{l}\text { - } \quad \text { Keinginan untuk meningkatkan } \\
\text { kemampuan diri } \\
\text { - } \quad \text { Belajar dalam kondisi alamiah } \\
\text { - } \quad \text { Belajar bukan karena paksaan } \\
\text { - Belajar karena kebutuhan diri }\end{array}$ \\
\hline & $\begin{array}{l}\text { Kontrol Pembelajar terhadap } \\
\text { Pembelajaran }\end{array}$ & $\begin{array}{l}\text { - } \quad \text { Menentukan tujuan belajar secara } \\
\text { mandiri } \\
\text { - } \quad \text { Menentukan materi belajar secara } \\
\text { mandiri } \\
\text { - } \quad \text { Menentukan metode belajar } \\
\text { - } \text { Mecara mandiri } \\
\text { Mengadakan evaluasi secara } \\
\text { mandiri }\end{array}$ \\
\hline
\end{tabular}

Populasi dalam penelitian ini adalah mahasiswa Program Studi Sarjana Teologi di STT Cipanas yang pada saat penelitian dilakukan berjumlah 98 orang mahasiswa. Dalam rangka menghemat biaya, waktu dan tenaga dalam penelitian ini maka diambil sampel sebanyak 78 orang mahasiswa dengan menggunakan teknik sampling simple random sampling. Adapun jumlah sampel sebanyak 78 orang mahasiswa diambil berdasarkan perhitungan sampel menggunakan rumus Slovin ${ }^{14}$ dengan tingkat kepercayaan $95 \%$ sebagaimana yang berlaku untuk ilmu-ilmu Sosial.

Teknik pengumpulan data yang digunakan adalah skala sikap, teknik ini digunakan karena data yang diungkap berupa persepsi mahasiswa. Dalam mengungkap data yang diperlukan digunakan skala sikap untuk mengungkap self-directed learning readiness mahasiswa yang dikembangkan dalam bentuk pernyataan tertutup, dengan empat alternatif jawaban, yaitu sangat setuju, setuju, tidak setuju dan sangat tidak setuju. Untuk pernyataan

${ }^{13}$ Darmayanti, 'Efektivitas Intervensi Keterampilan Self-Regulated Learning Dan Keteladanan Dalam Meningkatkan Kemampuan Belajar Mandiri Dan Prestasi Belajar Mahasiswa Pendidikan Jarak Jauh'.

${ }^{14}$ Adya Hermawati and Nasharuddin Mas, 'Transglobal Leadership, Quality of Work Life, and Employee Performance in Cooperatives in East Java, Indonesia', International Journal of Business Management , 1.1 (2016), 1-8 <https://sciarena.com/storage/models/article/qOKiof9QiZupkCkIfu2K1nuqikx5KBxRO2OE9g86ci4U505bsgLz 180rjlYt/transglobal-leadership-quality-of-work-life-and-employee-performance-in-cooperatives-in-east-java.pdf>. 
positif, masing-masing alternatif jawaban diberi skor 4, 3, 2, 1 sedangkan untuk item negatif diberi skor sebaliknya. Pengukuran variabel self-directed learning readiness mahasiswa melalui rating technique dengan teknik Likert Sumatied Ratings Scale dengan empat skala. Dengan pertimbangan bahwa skala Likert lima skala akan memunculkan kategori Undeciden dan menimbulkan kecenderungan jawaban ke tengah (central tendency effect). ${ }^{15}$ Sebelumnya semua pernyataan sikap telah diujicobakan dahulu ke lapangan untuk menguji validitas butir item dan reliabilitas instrumen. Hasil uji reliabilitas menunjukkan nilai reliabilitas Cronbach Alpha sebesar 0,82 lebih besar daripada 0.6, yang menunjukkan bahwa relibilitas instrumen dalam penelitian ini tinggi. Sementara hasil uji validitas butir item menunjukkan bahwa $r$ hitung > r tabel, yang berarti valid.

Teknik analisa data dalam penelitian ini menggunakan statistik deskriptif. Skala sikap yang sudah diisi dilakukan tabulasi data dengan memberikan skor di bawah ini :

Tabel 2. Skor Jawaban Responden

\begin{tabular}{|l|l|l|l|l|}
\hline Skor & SS & S & TS & STS \\
\hline Item Positif & 4 & 3 & 2 & 1 \\
\hline Item Negatif & 1 & 2 & 3 & 4 \\
\hline
\end{tabular}

(SS: Sangat Setuju; S: Setuju; TS: Tidak Setuju; STS: Sangat Tidak Setuju)

Setelah dibuat tabulasi data, untuk mengelompokkan jawaban responden maka di buat rentang menjadi tiga kelompok, tinggi, sedang, rendah.

Tabel 3: Rentang Jawaban Responden

\begin{tabular}{|l|l|}
\hline Rendah & $\mathrm{X}<\mathrm{M}-1 \mathrm{SD}$ \\
\hline Sedang & $\mathrm{M}-1 \mathrm{SD} \leq \mathrm{X}<\mathrm{M}+1 \mathrm{SD}$ \\
\hline Tinggi & $\mathrm{M}+1 \mathrm{SD} \leq \mathrm{X}$ \\
\hline Sumber: Azwar (2012) & \\
(M: Mean; SD: Standar Deviasi)
\end{tabular}

\section{Hasil dan Pembahasan}

Dalam bagian ini, dipaparkan hasil pengolahan data yang dilakukan berdasarkan penyebaran instrumen skala sikap kepada 78 mahasiswa yang menjadi responden dalam penelitian ini. Hasil penelitian memaparkan capaian self-directed learning readiness mahasiswa beserta dengan dimensi-dimensi yang diukurnya, meliputi dimensi otonomi diri, dimensi pengelolaan diri, dimensi kebutuhan belajar mandiri dan dimensi kontrol pembelajar terhadap pembelajaran.

Tabel 5: Self-directed learning readiness

\begin{tabular}{|c|c|c|c|c|c|}
\hline & & Frequency & Percent & Valid Percent & $\begin{array}{c}\text { Cumulative } \\
\text { Percent }\end{array}$ \\
\hline \multirow[t]{3}{*}{ Valid } & Sedang & 45 & 57.7 & 57.7 & 57.7 \\
\hline & Tinggi & 33 & 42.3 & 42.3 & 100.0 \\
\hline & Total & 78 & 100.0 & 100.0 & \\
\hline
\end{tabular}
1991).

${ }^{15}$ Sutrisno Hadi, Analisis Butir Untuk Instrumen Angket, Tes, Dan Skala Nilai (Yogyakarta: FP UGM,

${ }^{16}$ Saifuddin Azwar, Penyusunan Skala Psikologi (Yogyakarta: Pustaka Pelajar, 2012). 
Hasil pengolahan data dari 78 responden dalam penelitian ini menunjukkan bahwa sebesar $57.7 \%$ (45 orang) memiliki self-directed learning readiness sedang dan $42.3 \%$ (33 orang) memiliki self-directed learning readiness tinggi dan tidak ada responden yang memiliki selfdirected learning readiness rendah. Sementara skor rata-rata yang diperoleh sebesar 80.09, artinya self-directed learning readiness mahasiswa dalam penelitian ini termasuk sedang.

Tabel 6: Otonomi Diri

\begin{tabular}{|l|l|c|c|c|c|}
\hline \multicolumn{2}{|c|}{} & Frequency & Percent & Valid Percent & $\begin{array}{c}\text { Cumulative } \\
\text { Percent }\end{array}$ \\
\hline \multirow{3}{*}{ Valid } & Sedang & 45 & 57.7 & 57.7 & 57.7 \\
\cline { 2 - 6 } & Tinggi & 33 & 42.3 & 42.3 & 100.0 \\
\cline { 2 - 6 } & Total & 78 & 100.0 & 100.0 & \\
\hline
\end{tabular}

Hasil pengolahan data dari 78 responden dalam penelitian ini menunjukkan bahwa sebesar $57.7 \%$ (45 orang) dengan otonomi diri sedang dan $42.3 \%$ (33 orang) dengan otonomi diri tinggi dan tidak ada responden dengan otonomi diri rendah. Sementara skor rata-rata yang diperoleh sebesar 33.67, artinya otonomi diri mahasiswa dalam penelitian ini masih termasuk sedang.

Tabel 7: Pengelolaan Diri

\begin{tabular}{|l|l|c|c|c|c|}
\hline \multicolumn{2}{|c|}{} & Frequency & Percent & Valid Percent & $\begin{array}{c}\text { Cumulative } \\
\text { Percent }\end{array}$ \\
\hline \multirow{3}{*}{ Valid } & Sedang & 59 & 75.6 & 75.6 & 75.6 \\
\cline { 2 - 6 } & Tinggi & 19 & 24.4 & 24.4 & 100.0 \\
\cline { 2 - 6 } & Total & 78 & 100.0 & 100.0 & \\
\hline
\end{tabular}

Hasil pengolahan data dari 78 responden dalam penelitian ini menunjukkan bahwa sebesar 75.6\% (59 orang) memiliki pengelolaan diri yang sedang dan 24.4\% (19 orang) memiliki pengelolaan diri tinggi dan tidak ada responden yang memiliki pengelolaan diri yang rendah. Sementara skor rata-rata yang diperoleh sebesar 11.82, artinya pengelolaan diri mahasiswa dalam penelitian ini masih termasuk sedang.

Tabel 8: Kebutuhan Belajar Mandiri

\begin{tabular}{|l|l|c|c|c|c|}
\hline \multicolumn{2}{|c|}{} & Frequency & Percent & Valid Percent & $\begin{array}{c}\text { Cumulative } \\
\text { Percent }\end{array}$ \\
\hline \multirow{3}{*}{ Valid } & Sedang & 46 & 59.0 & 59.0 & 59.0 \\
\cline { 2 - 6 } & Tinggi & 32 & 41.0 & 41.0 & 100.0 \\
\cline { 2 - 6 } & Total & 78 & 100.0 & 100.0 & \\
\hline
\end{tabular}

Hasil pengolahan data dari 78 responden dalam penelitian ini menunjukkan bahwa sebesar 59\% (46 orang) memiliki kebutuhan belajar mandiri sedang dan 41\% (32 orang) memiliki kebutuhan belajar mandiri tinggi dan tidak ada responden yang memiliki kebutuhan belajar mandiri yang rendah. Sementara skor rata-rata yang diperoleh sebesar 27.65, artinya kebutuhan belajar mandiri mahasiswa dalam penelitian ini masih berada termasuk sedang. 
Tabel 9: Kontrol Pembelajar terhadap Pembelajaran

\begin{tabular}{|l|l|c|c|c|c|}
\hline \multicolumn{2}{|c|}{} & Frequency & Percent & Valid Percent & $\begin{array}{c}\text { Cumulative } \\
\text { Percent }\end{array}$ \\
\hline \multirow{3}{*}{ Valid } & Rendah & 1 & 1.3 & 1.3 & 1.3 \\
\cline { 2 - 6 } & Sedang & 24 & 30.8 & 30.8 & 32.1 \\
\cline { 2 - 6 } & Tinggi & 53 & 67.9 & 67.9 & 100.0 \\
\cline { 2 - 6 } & Total & 78 & 100.0 & 100.0 & \\
\hline
\end{tabular}

Hasil pengolahan data dari 78 responden dalam penelitian ini menunjukkan bahwa sebesar $1.3 \%$ (1 orang) memiliki kontrol terhadap pembelajaran yang rendah, $30.8 \%$ (24 orang) memiliki kontrol terhadap pembelajaran diri sedang dan sebesar 67.9\% (53 orang) memiliki kontrol terhadap pembelajaran yang tinggi. Sementara skor rata-rata yang diperoleh sebesar 6.95, artinya kontrol terhadap pembelajaran mahasiswa dalam penelitian ini termasuk tinggi.

\section{Pembahasan}

Hasil pengolahan data sebanyak 78 responden menunjukkan bahwa sebesar 57.7\% (45 orang) memiliki self-directed learning readiness sedang dan $42.3 \%$ (33 orang) memiliki self-directed learning readiness tinggi dan tidak ada responden yang memiliki self-directed learning readiness rendah. Sementara skor rata-rata yang diperoleh sebesar 80.09 yang termasuk kategori sedang, artinya self-directed learning readiness mahasiswa dalam penelitian ini termasuk sedang. Hasil penelitian ini sejalan dengan hasil penelitian yang dilakukan oleh Kusmawan, yang menemukan bahwa self-directed learning readiness mahasiswa guru Program Studi PGSD FKIP Universitas terbuka berada pada kategori sedang. ${ }^{17}$

Tabel: 10 Makna Skor (Modifikasi) Tingkat Kemandirian

\begin{tabular}{|l|l|}
\hline Rentang & Makna \\
\hline \multirow{5}{*}{$26-47$} & $\begin{array}{l}\text { Tingkat kemandirian Anda masih rendah. Anda masih harus } \\
\text { berusaha untuk menguasai kemampuan yang dituntut untuk dapat } \\
\text { menjadi pembelajar mandiri. Pelajari buku-buku yang berkenaan } \\
\text { dengan belajar mandiri. Usahakan untuk lebih mengenal diri Anda } \\
\text { sendiri. Pemahaman konsep diri yang baik akan membantu Anda } \\
\text { merancang kegiatan belajar yang sesuai dengan kemampuan yang Anda } \\
\text { miliki. }\end{array}$ \\
\hline Tingkat kemandirian Anda masih sedang. Untuk meningkatkan \\
kemandirian, Anda perlu lebih memahami kebutuhan belajar sehingga \\
Anda dapat memfokuskan pengelolaan belajar dalam memenuhi \\
kebutuhan tersebut. Anda juga masih harus terus berlatih untuk dapat \\
mengelola kegiatan belajar secara lebih efektif dan efisien.
\end{tabular}

Darmayanti memberikan makna terhadap pencapaian skor tingkat kemandirian mahasiswa, sebagaimana di lihat dari tabel di atas, ${ }^{18}$ dengan mencermati tabel di atas maka mahasiswa dengan self-directed learning readiness sedang belum sepenuhnya dapat

\footnotetext{
${ }^{17}$ Kusmawan.

18 Ibid.
} 
mengidentifikasi kebutuhan belajarnya, sehingga disarankan untuk meningkatkan kemampuan pengelolaan belajarnya melalui latihan. Hasil pengolahan data dimensi kebutuhan belajar mandiri dalam penelitian ini, menunjukkan bahwa mayoritas responden, sebesar 59\% (46 orang) memiliki kebutuhan belajar mandiri pada kategori sedang dan sisanya tinggi. Demikian pula, untuk dimensi pengelolaan diri, mayoritas responden sebesar $75.6 \%$ (59 orang) masih berada dalam kategori sedang, dan hanya 24.4\% (19 orang) responden saja yang memiliki pengelolaan diri yang termasuk dalam kategori tinggi. Sementara untuk dimensi otonomi diri, meskipun mayoritas responden 57.7\% (45 orang) masih berada dalam kategori sedang namun masih di bawah skor mayoritas responden untuk dimensi kebutuhan belajar mandiri dan dimensi pengelolaan diri. Begitu pula untuk dimensi kontrol pembelajar terhadap pembelajaran, mayoritas responden sedang hanya 30.8\% (24 orang), lebih banyak didominasi oleh mayoritas responden tinggi sebesar 67.9\% (53 orang).

Dengan mencermati kenyataan di atas, maka yang memberikan sumbangan terbesar bagi self-directed learning readiness mahasiswa yang berada dalam kategori sedang dalam penelitian ini yaitu dimensi pengelolaan diri dan kebutuhan belajar mandiri, sesuai dengan pemaknaan tingkat self-directed learning readiness yang disampaikan oleh Darmayanti. Jika Darmayanti menafsirkan bahwa untuk mahasiswa yang berada pada kategori sedang, kelemahan utamanya adalah dalam mengindentifikasi kebutuhan belajar mandiri sehingga perlu meningkatkan kemampuan mengelola diri, maka dalam penelitian ini justru kelemahan mahasiswa dengan self-directed learning readiness yang sedang, terletak pada kemampuan pengelolaan diri sehingga berdampak kepada kemampuan belajar mandirinya yang rendah. Meskipun demikian, bisa dikatakan bahwa terdapat hubungan yang erat antara kebutuhan belajar mandiri dengan kemampuan pengelolaan diri pada mahasiswa yang memiliki selfdirected learning readiness yang masih berada pada kategori sedang. Pengelolaan diri, sebagai faktor penting dalam self-directed learning readiness mahasiswa dalam penelitian ini menunjukkan bahwa kemampuan dan kemauan mahasiswa dalam mengelola diri perlu terus ditingkatkan dengan latihan dan memotivasi diri sendiri. Demikian juga dengan kemampuan mengidentifikasi kebutuhan belajar mandiri perlu terus dilatih, dengan cara mempergunakan setiap kesempatan yang diperoleh untuk belajar.

Kebutuhan belajar mandiri, sebagai salah satu dimensi kesiapan belajar mahasiswa, merupakan salah satu karakteristik orang dewasa, di mana mereka akan mempergunakan setiap kesempatan yang ada untuk belajar tanpa paksaan dari pihak lain. ${ }^{19}$ Hasil penelitian Supardi menemukan bahwa minat self-directed learning readiness mahasiswa Program Studi Pendidikan Perkantoran berada dalam kategori sedang, indikator yang digunakan untuk meneliti minat self-directed learning readiness mahasiswa dalam penelitian ini, yaitu 1) Perasaan suka dalam belajar, 2) Partisipasi dalam belajar, dan 3) Perhatian dalam belajar. Dengan mencermati hasil penelitian ini maka bisa dikatakan bahwa kebutuhan belajar mandiri sebagai faktor penting yang menentukan bagi mahasiswa dengan self-directed learning readiness yang sedang, dapat terjadi karena minat untuk untuk belajar mandiri yang juga masih belum optimal. Hal ini sesuai dengan penelitian yang dilakukan oleh Guglielmino \&

${ }^{19}$ Darmayanti, 'Efektivitas Intervensi Keterampilan Self-Regulated Learning Dan Keteladanan Dalam Meningkatkan Kemampuan Belajar Mandiri Dan Prestasi Belajar Mahasiswa Pendidikan Jarak Jauh'. 
Gugliemino $^{20}$ bahwa salah satu ciri mahasiswa yang memiliki kesiapan belajar yang tinggi, yaitu senang belajar. ${ }^{21}$ Unsur minat menjadi penting dalam menimbulkan kebutuhan belajar mandiri, karena berfungsi sebagai pendorong seseorang untuk melakukan aktivitas belajar mandiri, tanpa adanya minat yang tinggi maka kebutuhan seseorang untuk belajar mandiri juga tidak akan optimal. Sehingga bisa dikatakan bahwa kebutuhan belajar mandiri yang masih berada pada kategori sedang bisa menjadi sebuah indikasi kurangnya minat mahasiswa dalam belajar mandiri pada penelitian ini.

Dengan mencermati hasil penelitian Kusmawan dan Supardi, maka terdapat kesamaan hasil, yaitu tingkat self-directed learning readiness mahasiswa di Program Studi PGSD Universitas Terbuka, mahasiswa di Program Studi Pendidikan Perkantoran dan mahasiswa di Program Studi Teologi STT Cipanas berada dalam tingkat yang sedang. Namun hasil penelitian ketiganya, berbeda dengan hasil penelitian Dewi yang menemukan bahwa Selfdirected learning readiness Mahasiswa Kedokteran Universitas Lampung justru mayoritas sebesar $78.4 \%$ termasuk kategori tinggi, $21.6 \%$ sedang dan tidak ada yang rendah. ${ }^{22}$ Demikian pula hasil penelitian Lutfianawati et al menemukan bahwa tingkat self-directed learning readiness Mahasiswa Kedokteran Universitas Malahayati mayoritas $90.9 \%$ berada pada kategori tinggi, $6.6 \%$ sedang dan $2.5 \%$ rendah. ${ }^{23}$ Begitu pula dengan penelitian Senthya yang menemukan bahwa self-directed learning readiness mahasiswa Kedokteran Universitas Lampung mayoritas $82.5 \%$ berada dalam kategori tinggi. ${ }^{24}$ Dengan membandingkan hasil penelitian bisa dikatakan bahwa self-directed learning readiness mahasiswa di Fakultas Kedokteran lebih tinggi dibandingkan self-directed learning readiness mahasiswa di Jurusan Pendidikan dan Teologi. Slameto mengatakan bahwa belajar dipengaruhi oleh faktor internal dan eksternal. ${ }^{25}$ Faktor internal meliputi faktor jasmani, faktor psikologis dan faktor kelelahan sedangkan faktor eksternal meliputi faktor keluarga, faktor sekolah dan faktor masyarakat. Sehingga bisa dikatakan bahwa adanya perbedaan kesiapan belajar mahasiswa, bisa terjadi karena adanya perbedaan dari faktor-faktor yang memengaruhi aktivitas belajar itu sendiri, dan karena perbedaan hasil ini terjadi dalam lingkup jurusan, maka yang paling mungkin adalah pola pendidikan (faktor sekolah) di fakultas kedokteran yang memiliki kekhasan.

Self-directed learning readiness mahasiswa memiliki pengaruh yang penting terhadap keberhasilan mahasiswa dalam menempuh pendidikan jarak jauh yang sudah dilaksanakan selama beberapa bulan ini, untuk mencegah penularan Covid-19. Hasil penelitian Darmayanti, menemukan bahwa self-directed learning readiness mahasiswa memiliki korelasi yang positif

${ }^{20}$ L.M. Guglielmino and P.J. Guglielmino, Expanding Your Readiness for Self Directed Learning (Ontario: Organization and Development Inc, 1991).

${ }^{21}$ Puspitasari and Islam.

${ }^{22}$ Indah Anita Dewi, 'HUBUNGAN KECERDASAN EMOSIONAL DENGAN KESIAPAN BELAJAR MANDIRI MAHASISWA DI FAKULTAS KEDOKTERAN UNIVERSITAS LAMPUNG' (Universitas Lampung, 2019).

${ }^{23}$ Dewi Lutfianawati and others, 'Hubungan Kesiapan Belajar Mandiri Dengan Tingkat Kecemasan Pada Mahasiswa Tahun Pertama Fakultas Kedokteran Universitas Malahayati Tahun 2017', Jurnal Ilmu Kedokteran Dan Kesehatan, 5.4 (2018), 232-44.

${ }^{24}$ Erisa Senthya and others, 'Hubungan Motivasi Belajar Terhadap Self Directed Learning Readiness Mahasiswa Fakultas Kedokteran Universitas Lampung The Relationship Between Learning Motivation and Self Directed Learning Readiness Student in Medical Faculty of Lampung University', 6.1 (2019), 139-44.

${ }^{25}$ Slameto, Belajar Dan Faktor-Faktor Yang Mempengaruhinya (Jakarta: Rineka Cipta, 2010). 
dengan prestasi belajar mahasiswa yang menempuh pendidikan jarak jauh di Universitas Terbuka sebesar 0.24. Hal ini membuktikan bahwa keberhasilan pendidikan jarak jauh yang sudah dilakukan selama beberapa bulan ini di perguruan tinggi, akan berdampak kepada prestasi belajar mahasiswa. Self-directed learning readiness mahasiswa yang tinggi tentunya akan berdampak kepada prestasi belajar mahasiswa yang tinggi juga, begitu pula sebaliknya. Hasil penelitian, kesiapan belajar mahasiswa teologi di STT Cipanas yang masih berada dalam kategori sedang, akan berdampak kepada prestasi belajar mahasiswa juga, sehingga diperlukan intervensi untuk meningkatkan kesiapan belajar mahasiswa dalam rangka mencapai prestasi belajar yang tinggi dalam melaksanakan pendidikan jarak jauh di masa depan pasca-pandemi Covid-19.

Penelitian Darmayanti, menemukan bahwa intervensi Psikologis yang biasa dilakukan di ruang kelas ternyata efektif juga untuk meningkatkan kebutuhan belajar siswa yang merupakan salah satu komponen self-directed learning readiness mahasiswa. ${ }^{26}$ Intervensi Psikologis, yang biasa dilakukan oleh dosen di ruang kelas, merupakan strategi pembelajaran yang biasa dilakukan oleh dosen di dalam kelas agar mahasiswa mencapai kompetensi yang diharapkan selama pembelajaran, dari mulai mengingatkan mahasiswa akan tujuan belajar yang hendak dicapai, memberikan motivasi kepada mahasiswa, memberikan tugas, memberikan kuis, akan cukup efektif dalam meningkatkan kemampuan belajar mandiri mahasiswa dalam melaksanakan modus pendidikan jarak jauh di masa depan pasca-pandemi Covid-19 ini.

\section{Kesimpulan}

Self-directed learning readiness mahasiswa Sekolah Tinggi Teologi Cipanas dalam melaksanakan PJJ di masa pandemi Covid-19 ini, memperoleh skor rata-rata sebesar 80.9 dari skor ideal 104 artinya self-directed learning readiness mahasiswa masih berada pada kategori sedang. Penelitian ini mengukur kesiapan belajar mahasiswa dengan empat dimensi, yaitu otonomi diri, pengelolaan diri, kebutuhan belajar mandiri, dan kontrol pembelajar terhadap pembelajaran. Dari empat dimensi self-directed learning readiness yang diukur dalam penelitian ini, mayoritas mahasiswa masih berada kategori sedang. Dimensi pengelolaan diri, 75.6\% mahasiswa masih berada pada kategori sedang. Dimensi kebutuhan belajar mandiri, 59\% mahasiswa berada pada kategori sedang. Dimensi otonomi diri 57.7\% mahasiswa berada pada kategori sedang. Tapi untuk dimensi kontrol pembelajar terhadap pembelajaran mayoritas mahasiswa $67.9 \%$ mahasiswa sudah berada pada kategori tinggi.

Karena self-directed learning readiness mahasiswa Sekolah Tinggi Teologi Cipanas dalam melaksanakan PJJ di masa pandemi Covid-19 masih berada pada kategori sedang maka untuk meningkatkan self-directed learning readiness mahasiswa menghadapi pembelajaran pasca-pandemi Covid-19, perlu dilakukan identifikasi terhadap kebutuhan belajar mandiri mahasiswa sehingga kompetensi yang harus dikuasai oleh mahasiswa bisa lebih sesuai dengan kebutuhan belajar mandirinya dan perlu dibuat jadwal pelaksanaan PJJ yeng lebih jelas untuk setiap mata kuliah yang akan melaksanakan kuliah daring disertai dengan jadwal

${ }^{26}$ Darmayanti, 'Efektivitas Intervensi Keterampilan Self-Regulated Learning Dan Keteladanan Dalam Meningkatkan Kemampuan Belajar Mandiri Dan Prestasi Belajar Mahasiswa Pendidikan Jarak Jauh'. 
pengumpulan tugas terstruktur dan jadwal belajar mandiri mahasiswa. Jika tidak dilakukan maka prestasi belajar mahasiswa selama mengikuti PJJ pasca pandemi COVID-19 dapat menurun.

\section{Referensi}

Azwar, Saifuddin, Penyusunan Skala Psikologi (Yogyakarta: Pustaka Pelajar, 2012)

Candy, Philip C, Self-Direction for Lifelong Learning , A Comprehensive to Theory and Practice (San Fransisco: Jossey-Bass Inc, 1991)

Darmayanti, Tri, 'Efektivitas Intervensi Keterampilan Self-Regulated Learning Dan Keteladanan Dalam Meningkatkan Kemampuan Belajar Mandiri Dan Prestasi Belajar Mahasiswa Pendidikan Jarak Jauh' (Universitas Indonesia, 2005)

_ Terbuka (The Indonesian Open Learning University)' (University of Victoria, 1993)

Dewi, Indah Anita, 'HUBUNGAN KECERDASAN EMOSIONAL DENGAN KESIAPAN BELAJAR MANDIRI MAHASISWA DI FAKULTAS KEDOKTERAN UNIVERSITAS LAMPUNG' (Universitas Lampung, 2019)

Dikti, Humas Ditjen, 'Kebijakan Dan Penelitian Perguruan Tinggi Untuk Hadapi Pandemi Covid-19 - Dikti Official Site', Kementerian Pendidikan Dan Kebudayaan, 2020 <http://www.dikti.go.id/kabar/ditjen-dikti-berupaya-mendorong-dan-berfokus-padakebijakan-progam-menghadapi-pandemi-covid-19/> [accessed 10 May 2020]

Elvis, Martin, 'Perpanjangan Aktivitas Perkuliahan Online', 2020, pp. 1-2

- 'Surat Edaran Terkait Sikap STT Cipanas Terhadap Covid-19', 2020, pp. 1-2

Guglielmino, L.M., and P.J. Guglielmino, Expanding Your Readiness for Self Directed Learning (Ontario: Organization and Development Inc, 1991)

Hadi, Sutrisno, Analisis Butir Untuk Instrumen Angket, Tes, Dan Skala Nilai (Yogyakarta: FP UGM, 1991)

Hermawati, Adya, and Nasharuddin Mas, 'Transglobal Leadership, Quality of Work Life, and Employee Performance in Cooperatives in East Java, Indonesia', International Journal of Business Management , 1.1 (2016), 1-8

$<$ https://sciarena.com/storage/models/article/qOKiof9QiZupkCkIfu2K1nuqikx5KBxRO 2OE9g86ci4U505bsgLz180rjlYt/transglobal-leadership-quality-of-work-life-andemployee-performance-in-cooperatives-in-east-java-.pdf>

Kontri, 'Menag Minta Pimpinan PTK Ambil Langkah Tegas Cegah Corona', Kementerian Agama, $2020<$ https://kemenag.go.id/berita/read/513018/menag-minta-pimpinan-ptkambil-langkah-tegas-cegah-corona $>$ [accessed 10 May 2020]

Kusmawan, Udan, 'Kesiapan Belajar Mandiri Guru Sekolah Dasar Sebagai Mahasiswa Pada Program Studi Pgsd Fkip Universitas Terbuka Self-Directed Learning Readiness of Elementary School Teacher As Student of Open University', Jurnal Pendidikan Dan Kebudayaan, 1 (2016), 279-93 <http://jurnaldikbud.kemdikbud.go.id>

Lutfianawati, Dewi, Sri Maria, Puji Lestari, Septa Istiana, Prodi Psikologi, Fakultas Kedokteran, and others, 'Hubungan Kesiapan Belajar Mandiri Dengan Tingkat Kecemasan Pada Mahasiswa Tahun Pertama Fakultas Kedokteran Universitas Malahayati Tahun 2017', Jurnal Ilmu Kedokteran Dan Kesehatan, 5.4 (2018), 232-44

Mendikbud, 'Surat Edaran Mendikbud No. 35952/MPK.A/HK/2020 Tentang Pembelajaran Secara Daring Dan Bekerja Dari Rumah Dalam Rangka Pencegahan Penyebaran Corona Virus Disease (Covid-19)', Produk Hukum, 2020, pp. 1-2 $<$ https://www.kemdikbud.go.id/main/blog/2020/03/se-mendikbud-pembelajaran-secaradaring-dan-bekerja-dari-rumah-untuk-mencegah-penyebaran-covid19> 
Puspitasari, Kristanti Ambar, and Samsul Islam, 'Kesiapan Belajar Mandiri Mahasiswa Dan Calon Potensial Mahasiswa Pada Pendidikan Jarak Jauh Di Indonesia', Jurnal

Pendidikan Terbuka Dan Jarak Jauh, 4.1 (2003), 1-13

<http://simpen.lppm.ut.ac.id/ptjj/PTJJ Vol 4.1 maret 2003/41kristanti.htm>

Senthya, Erisa, Br Surbakti, Dwita Oktaria, Fakultas Kedokteran, Universitas Lampung,

Bagian Pendidikan Kedokteran, and others, 'Hubungan Motivasi Belajar Terhadap Self

Directed Learning Readiness Mahasiswa Fakultas Kedokteran Universitas Lampung

The Relationship Between Learning Motivation and Self Directed Learning Readiness

Student in Medical Faculty of Lampung University', 6.1 (2019), 139-44

Slameto, Belajar Dan Faktor-Faktor Yang Mempengaruhinya (Jakarta: Rineka Cipta, 2010)

Yulianasyah, Meningkatkan Response Rate Pada Penelitian Survey Suatu Studi Literature (Jakarta: SMART, 2016) 